\title{
ZAGADNIENIE WIARY W NAUCZANIU KAZNODZIEJSKIM ŚW. CHROMACJUSZA Z AKWILEI
}

Badacze antyku chrześcijańskiego niewiele miejsca w swych badaniach poświęcają twórczości św. Chromacjusza ${ }^{1}$, biskupa Akwilei. Tymczasem lektura spuścizny literackiej Chromacjusza², na którą składają się jego kazania i homilie ${ }^{3}$, pozwala dostrzec $\mathrm{w}$ nim mistrza kaznodziejstwa liturgicznego ${ }^{4}$, mogącego stać się wzorem kaznodziejskiego kunsztu także dla współczesnych głosicieli Dobrej Nowiny. Nie bez znaczenia dla pozytywnej oceny wartości jego kaznodziejskiego przepowiadania wydaje się być strona językowa jego kazań. Dające się w nich zauważyć krótkie zdania, prosty i dość

${ }^{*}$ Ks. dr Brunon Zgraja - adiunkt w Katedrze Historii Kościoła i Patrologii na Wydziale Teologii Uniwersytetu Opolskiego; e-mail: zgrb@op.pl.

${ }^{1}$ Do grona badaczy twórczości Chromacjusza należą: M. Sołomieniuk, Chromacjusz z Awilei i Zenon z Werony o zmartwychwstaniu, „Studia Gnesnensia” 26 (2012) 45-67; C. Corsato, Il profeta Elia in Cromazio di Aquileia. Un giusto dal cuore puro nella tempesta delle proce (persecutione, deserto, castia), „Studia Patavina” 57 (2010) 183-197; G. Trettel, La croce di Constantino e la croce di Cromazio (dai Sermoni), „Studia Patavina” 56 (2009) 359-378; G. Rapisarda, Continuità tra Antico e Nuovo Testamento in Cromazio di Aquileia, „Augustinianum” 40 (2000) 291-302; P. Zovatto, Intorno a due recenti studi su s. Cromazio di Aquileia, „Divinitas” 24 (1980) 98-104; P.F. Beatrice, Due nuovi testamenti della lavanda dei piedi età patristica. Cromazio di Aquileia e Severiano di Gabala, „Augustinianum” 20 (1980) 23-54; G. Trettel, Terminologia esegetica nei sermoni di san Cromazio di Aquileia, REAug 20 (1974) 55-81; J. Lemarié, Le térmoignage du martyre d'apries les sermons de Chromace d'Aquilée, RSLR 5 (1996) 3-12; P.F. Beatrice, The Sign of Jonah. The Paschal Mystery and the Conversion of the Pagans according to Chromatius of Aquileia, w: Chromatius of Aquileia and His Age. Proceedings of the International Conference held in Aquileia, 22-24 May 2008, ed. P.F. Beatrice - A. Peršič, Turnhout 2011, 19-64.

${ }^{2}$ Św. Chromacjusz urodził się ok. 335 r., prawdopodobnie w Akwilei, gdzie przez blisko dwadzieścia lat był biskupem. Zmarł w roku 407 lub 408, prawdopodobnie w Grado, jako wygnaniec. Więcej na jego temat zob. A. Bober - J. Misiurek, Chromacjusz, EK III 280-281; J. Lemarié, Chromace d'Aquilée, DSAM VII 2162-2165; G. Cuscito, Introduzione, w: Cromazio di Aquileia. Catechesi al popolo, ed. G. Cuscito, Roma 1979, 7-35.

${ }^{3}$ Kazania Chromacjusza zostały wydane w serii „Sources Chrétiennes”: Chromace d'Aquilée, Sermons, I: Sermons 1-17A, Introduction, texte critique, notes par J. Lemarié, traduction par H. Tardif, SCh 154, Paris 1969; II: Sermons 18-41, Introduction, texte critique, notes par J. Lemarié, traduction par H. Tardif, SCh 164, Paris 1971. Całą jego spuściznę, a więc kazania i homilie, wydali natomiast J. Lemarié i R. Étaix w serii „Corpus Christianorum. Series Latina”: Chromati Aquileiensis opera, CCL 9A, Turnhout 1974.

${ }^{4}$ Por. V. Cian, L'anno litirgico nelle opera di s. Cromazio di Aquileia, Trieste 1996, 26-27. 
żywy język Chromacjusza, jak również wyczuwalna troska o dobro słuchaczy, pozbawiona natrętnego moralizatorstwa ${ }^{5}$, stanowią bowiem o ponadczasowym walorze stylu jego przepowiadania, mającym niemały wpływ na jego komunikatywność.

Innym, nie mniej ważnym elementem strony językowej kazań Chromacjusza, która jako istotny czynnik ich komunikatywności ${ }^{6}$ winna stanowić jeden z obszarów naukowej refleksji nad jego spuścizna, jest wielość obrazów i porównań, przy pomocy których biskup Akwilei objaśniał swoim wiernym tajemnicę Chrystusa ${ }^{7}$ i Kościoła ${ }^{8}$. Godne naśladowania unikanie w przepowiadaniu języka abstrakcyjnego, który nierzadko stanowi istotną przeszkodę $\mathrm{w}$ zrozumieniu jego treści, staje się jednak widoczne u Chromacjusza zwłaszcza przy omawianiu zagadnienia wiary. Biskup Akwilei, mając na uwadze zdolności percepcyjne słuchaczy swoich kazań, dokonywał w nich wykładni tego zagadnienia poprzez odwoływanie się do biblijnych wydarzeń, znaków i symboli interpretowanych w duchu alegorycznym. Obrazowy charakter nauczania, jak również obecna w nim alegoryczna interpretacja bogatego w Biblii świata obrazów, symboli i znaków, choć niejednokrotnie wyszukana i wyrosła z wybujałej wyobraźni Chromacjusza, bez wątpienia czyniły cały przekaz prostym, a co ważniejsze - interesującym ${ }^{9}$, a zarazem komunikatywnym.

Badania lingwistyczne, o których wspomniano powyżej, to ważny, ale nie jedyny, otwarty obszar naukowej refleksji nad twórczością kaznodziejską biskupa Akwilei. W obszarze tym, oprócz szerokiego kręgu zagadnień natury dogmatycznej ${ }^{10}$, widzieć należy także, zasygnalizowaną powyżej, kwestię wiary. Prześledzenie nauczania biskupa Chromacjusza w tej materii wydaje się być interesujące, bynajmniej nie tylko z powodu wspomnianego już obrazowego charakteru wykładni tego zagadnienia. Konieczność ochrony czystości wiary przed arianizmem niesionym przez gockich najeźdźców ${ }^{11}$, przed jaką stanął gorliwy biskup-duszpasterz, winna bowiem, jak należałoby przypuszczać, nadać całemu jego przepowiadaniu na temat wiary charakter apologetyczno-polemiczny, widoczny chociażby w odniesieniu do Żydów ${ }^{12}$, którzy nie uwierzyli w Chrystusa pomimo świadectw Starego Testamentu oraz Apostołów.

\footnotetext{
${ }^{5}$ Por. J. Lemarié, Introduction: Le prédicateur. L’homme et le style, w: SCh 154, 55-62.

${ }^{6}$ Więcej na temat komunikatywności przepowiadania zob. m.in.: Z. Grzegorski, Postuga stowa w schemacie teorii komunikacji, STV 8 (1970) nr 1, 479-507; L. Kuc, Komunikacja z Chrystusem, w: Studia z teorii kaznodziejstwa i homiletyki, t. 2, red. W. Wojdecki, Warszawa 1980, 50-95.

${ }^{7}$ Por. Chromatius Aquileiensis, Sermo 4, 2; 8, 2; 11, 4; 31, 1; 32, 2.

${ }^{8}$ Por. tenże, Sermones 3, 5; 3, 6; 15, 4; 33, 4.

${ }^{9}$ Por. E. Stanula, Wstęp, w: Chromacjusz z Akwilei, Kazania i homilie, thum. S. Ryznar, PSP 49, Warszawa 1990, 10.

${ }^{10}$ Zagadnienia te w pewnym stopniu, ale jedynie w odniesieniu do Sermones omawia J. Lemarié (Introduction: Le prédicateur. La doctrine, SCh 154, 62-81).

${ }^{11}$ Por. Bober - Misiurek, Chromacjusz, EK III 280.

${ }^{12}$ Por. Chromatius Aquileiensis, Sermones 9, 2-5; 10, 3-4; 12, 1; 13, 1-2; 27, 2; 28, 1-2.
} 
Czy nauczanie Chromacjusza ${ }^{13} \mathrm{w}$ tej ważnej dla chrześcijanina kwestii, z racji szerzącej się herezji arianizmu, rzeczywiście nosi również znamiona polemiki, koncentrującej się głównie na doktrynalnym jej aspekcie, niewiele, jak się wydaje, wnoszącej do praktyki wiary, czy też jest rzeczową wykładnią zagadnienia wiary, podejmowaną przez biskupa Akwilei z zauważalną troską o zbawienie swoich wiernych, mobilizującą do owocnego jej praktykowania i przeżywania? Poniższe punkty niniejszego artykułu (1. Istota wiary; 2. Owoce wiary; 3 . Niebezpieczeństwo utraty wiary), wyznaczające jego treść, zdają się w pewnym sensie stanowić też odpowiedź na powyższe pytania.

1. Istota wiary. Czym jest wiara w swojej istocie, wyjaśnia biskup Akwilei już w pierwszym swoim kazaniu w kontekście opisanego w Dziejach Apostolskich (3,1-11) wydarzenia uzdrowienia chromego, którego utożsamiać należy zarówno z narodem żydowskim, jak i z każdym innym człowiekiem. Owo uzdrowienie, co jest ważne dla zrozumienie istoty wiary, oznacza według Chromacjusza, uzdrowienie zarówno umysłu człowieka, jak i jego ducha. Jak stwierdza bowiem nasz kaznodzieja, ,chromaliśmy zaś nie krokami ciała, ale postępowaniem umysłu i ducha"14. Uzdrowienie z chromania, będącego oznaką choroby zarówno umysłu, jak i ducha, objawiającego się kroczeniem po drogach nieprawości prowadzących do choroby ducha, wymaga jednak zdaniem biskupa Akwilei - uwolnienia się najpierw od choroby umysłu, którą powoduje nieznajomość Chrystusa:

„Kto mija się z drogą sprawiedliwości, kto zbacza z drogi prawdy, ten cały jest kulawy, chociażby miał zdrowe, proste nogi, ponieważ kuleje umysłowo i duchowo. [...] Stąd bez wątpienia chromaliśmy od dawna poza drogą sprawiedliwości, gdy nie znaliśmy Chrystusa Pana, prawdziwej drogi zbawienia i życia" $"$.

Warunkujące zdrowie umysłu poznanie Chrystusa, będącego jedyną, prawdziwą drogą zbawienia i życia, daje jednak - jak należy sądzić - jedynie okazję do poznania jedynej, prawdziwej drogi prowadzącej do zdrowia ducha (a tym samym do zbawienia), jaką jest droga sprawiedliwości. Zdrowie umysłu przynosi bowiem dopiero całkowita akceptacja tej drogi przez umysł, rodząca jednocześnie moralny imperatyw do podążania nią. Owa akceptacja, gwarantująca zdrowie umysłu, albo jak mówi Chromacjusz - wyprostowanie się kroków myśli ${ }^{16}$, jest z kolei niczym innym, jak uwierzeniem, a więc uznaniem

${ }^{13}$ Przez nauczanie Chromacjusza należy rozumieć jego kazania (Sermones), w których znajduje się najwięcej odniesień do omawianego zagadnienia wiary.

${ }^{14}$ Chromatius Aquileiensis, Sermo 1, 4, SCh 154, 128, thum. S. Ryznar: Chromacjusz z Akwilei, Kazania i homilie, PSP 49, Warszawa 1990, 16.

${ }^{15}$ Tamże.

${ }^{16}$ Por. tamże. 
za przekonywujący, a zarazem i prawdziwy przekaz Ewangelii ${ }^{17}$, ukazujący Chrystusa jako jedyną prawdziwą drogę prowadzącą do zdrowia ducha:

„Lecz skoro przybyliśmy pod Piękną bramę świątyni i spojrzeliśmy na Apostołów Chrystusa z wiara, wtedy wyprostowały się kroki myśli naszej [...]. Przybyliśmy bowiem [...] pod Piękną bramę świątyni, gdzie chorzy zwykle doznawali uzdrowienia. Piękną bramą świątyni jest głoszenie Ewangelii [...] i pod nią otrzymują zdrowie zbawienia chorzy na umyśle [...]"18.

Samo poznanie Chrystusa, prowadzące do uzdrowienia umysłu, nie skutkuje automatycznie, co również należy podkreślić, zdrowiem ducha. Powrót do zdrowia ducha wymaga bowiem najpierw okazania posłuszeństwa woli, która motywowana do działania przez zdrowy umysł, nakłania do wejścia na drogę sprawiedliwości, której początek stanowi chrzest święty. Fakt ten, jak się wydaje, uświadamia biskup Chromacjusz swoim wiernym, przywołując w jednym z kazań postać eunucha z Dziejów Apostolskich $(8,25-34)$, który po wyjaśnieniu mu przez Filipa pism prorockich, wskazujących na Chrystusa, uwierzył w Niego i podjął decyzję o przyjęciu chrztu ${ }^{19}$. Choć jednak już sam chrzest przynosi zdrowie ducha, a więc uwolnienie od nieprawości ${ }^{20}$, o czym przypomina Chromacjusz, porównując ochrzczonego eunucha do gołębia, który z kruka, a więc człowieka pozostającego w czerni grzechu stał się człowiekiem czystym, a więc bezgrzesznym ${ }^{21}$, to przyjęcie tego sakramentu stanowi, jak o tym już wspomnieliśmy, jedynie rozpoczęcie podążania drogą sprawiedliwości. Oznacza to, że będący oznaką zdrowia ducha, otrzymany na chrzcie stan bezgrzeszności, wymaga nieustannego pielęgnowania, co wiąże się z koniecznością nieustannego kroczenia obraną drogą. Obrazowo mówi o tym Chromacjusz, wskazując na znanego jego słuchaczom z Dziejów Apostolskich Szymona Maga (Dz 8, 9-22), który po przyjęciu chrztu uległ podszeptom szatana i, chcąc za pieniądze kupić od apostołów władzę nakładania rąk w celu udzielania tą drogą Ducha Świętego, wszedł tym samym na drogę nieprawości ${ }^{22}$.

Powyższe rozważania i stwierdzenia nie są bez znaczenia dla ukazania istoty wiary. Wyłaniająca się bowiem z nich konkluzja, o konieczności kroczenia poznaną dzięki Chrystusowi i w pełni zaakceptowaną drogą sprawiedliwości - będąca owocem analiz różnych wypowiedzi biskupa, służących wyjaśnieniu zasygnalizowanej w 1. kazaniu kwestii istoty aktu wiary - jest wezwaniem do podążania drogą wiary. Podążanie tą drogą jest zaś dla Chromacjusza niczym innym, jak właśnie postępowaniem drogą sprawiedliwości²3.

\footnotetext{
${ }^{17}$ Por. tenże, Sermo 11, 3.

${ }^{18}$ Tenże, Sermo 1, 4, SCh 154, 128-130, PSP 49, 16-17.

${ }^{19}$ Por. tenże, Sermo 2, 7.

${ }^{20}$ Por. tenże, Sermo 15, 5-6; 18, 3-4; 34, 3.

${ }^{21}$ Por. tenże, Sermo 2, 5-7.

${ }^{22}$ Por. tamże 2, 3-4

${ }^{23}$ Por. tenże, Sermo 1, 4.
} 
By móc postępować drogą wiary, konieczne jest więc, co wykazały zresztą wcześniejsze analizy, poznanie Chrystusa, zaś samo postępowanie tą drogą, to - krótko mówiąc - nic innego, jak nieustanna wierność Jego nauce. Akt wiary, jakim jest podążanie drogą sprawiedliwości, nie sprowadza się zatem tylko do aspektu wolitywnego. Nierozdzielnie bowiem jest z nim związany, warunkujący go - aspekt doktrynalny. To bowiem poznanie, dzięki głoszonej Ewangelii, nauki Chrystusa ${ }^{24}$, będącego drogą zbawienia, i całkowita akceptacja tej drogi, stoją u podstaw decyzji podjęcia trudu kroczenia drogą wolną od nieprawości, mającej swój początek w sakramencie chrztu. Zależność tę, jak pamiętamy, ukazał Chromacjusz na przykładzie związku, jaki istnieje pomiędzy zdrowiem ducha a zdrowiem umysłu ${ }^{25}$.

Wypada jednak zauważyć, że biskup Akwilei mówiąc o postępowaniu drogą wiary, wydaje się w ten sposób sprowadzać wiarę do aktu wolitywnego, przejawiającego się w kroczeniu drogą sprawiedliwości, deprecjonując tym samym niejako jej aspekt doktrynalny. Zarzut ten nie znajduje jednak żadnego uzasadnienia w kaznodziejskim przepowiadaniu biskupa. Wręcz przeciwnie. $\mathrm{Na}$ istotną rolę wspomnianego aspektu w akcie wiary zwraca uwagę nasz kaznodzieja w kazaniu 11., kiedy to na kanwie alegorycznej interpretacji sceny namaszczenia przez Marię stóp Chrystusa, wyraźnie daje do zrozumienia swoim słuchaczom, iż zbawienie wymaga wiary we wcielenie i w bóstwo Chrystusa:

„Zwróć uwagę, że w owej niewieście została na przyszłość wskazana tajemnica wiary. Nie namaściła od razu głowy Pana, ale nogi. W nogach Chrystusa ukazuje nam Ewangelista jakby tajemnicę Jego Wcielenia, w której w tych ostatnich czasach raczył się narodzić z Dziewicy. W głowie natomiast widzimy symbol chwały Jego Bóstwa, w którym przed wszystkimi wiekami pochodził od Ojca. Dlatego Kościół najpierw podszedł do nóg Pana, a następnie do głowy, ponieważ jeżeliby nie poznał i nie nauczył się o Wcieleniu Jego z Dziewicy, nigdy nie mógłby pojąć chwały Jego Bóstwa, które od Ojca pochodzi. I dlatego czytamy, co napisano o baranku ofiarnym pod Prawem jako zapowiedzi tajemnicy Chrystusa: «Pożywać będziecie z głową i nogami» (Wj 12, 9), i to jest, że mamy w obydwie tajemnice Chrystusa wierzyć: że jest On i Bogiem i człowiekiem. Bogiem z Ojca, człowiekiem z Dziewicy. Bo, jak powiedzieliśmy, w głowie jest wskazane Jego Bóstwo od Ojca pochodzące, w nogach natomiast Jego Wcielenie z Dziewicy. Innym sposobem nie możemy się zbawić, jak tylko wierząc w obydwie tajemnice Chrystusowe"26.

Stwierdzenie to, powodowane zapewne troską biskupa o czystość wiary zagrożonej arianizmem, wydaje się być - w kontekście naszych rozważań o tyle słuszne, iż zbawienie będące owocem kroczenia drogą sprawiedliwości, wymaga uprzedniego poznania tej drogi, a więc Chrystusa, co staje się

\footnotetext{
${ }^{24}$ Por. tenże, Sermo 11, 3.

${ }^{25}$ Por. tenże, Sermo 1, 4.

${ }^{26}$ Tenże, Sermo 11, 4, SCh 154, 218-220, PSP 49, 43. Por. tenże, Sermo 9, 5.
} 
możliwe dzięki wcieleniu. Ten, kto nie akceptuje tego wydarzenia, można powiedzieć, iż pozbawia siebie możliwości poznania Chrystusa-drogi, a jednocześnie możliwości zbawienia. Postępowanie drogą sprawiedliwości, a więc drogą wiary, wiąże się zatem dla Chromacjusza z koniecznością uznania faktu wcielenia. Akceptacja tego wydarzenia, dająca możliwość uznania skutków wcielenia, w tym także i nauczania Chrystusa, stanowi zatem bezsprzecznie zasadniczy element aspektu doktrynalnego, a zarazem podstawę całego aktu wiary. Jak zatem nie trudno dostrzec, Chromacjusz wyjaśniając swoim wiernym istotę aktu wiary, nie tylko uzmysławia im priorytetową rolę aspektu doktrynalnego w całym akcie wiary, co nadaje mu wyraźną treść.

Choć aspekt doktrynalny stanowi, jak dało się to zauważyć, podstawę, a tym samym uzasadnienie dla podążania drogą sprawiedliwości, to można odnieść wrażenie, iż biskup Chromacjusz poświęca mu niewiele miejsca w swoich kazaniach. Taka postawa biskupa słusznie rodzić może niezrozumienie. Wprawdzie do przyjęcia jest minimalizm - o ile można tak powiedzieć na marginesie naszych rozważań - w aspekcie doktrynalnym aktu wiary, bo akceptacja stanowiącego jego treść faktu wcielenia i jego skutków zdaje się stanowić wystarczającą motywację dla aktu wolitywnego, ale trudno znaleźć racje uzasadniające raczej marginalne traktowanie wielu zagadnień, istotnych w obliczu zagrożenia arianizmem ${ }^{27}$. Wytłumaczeniem tego faktu wydaje się być świadomość trudu związanego z podążaniem drogą sprawiedliwości ${ }^{28}$ - będącego źródłem zniechęcenia, a także i niejednokrotnie przyczyną rezygnacji z kroczenia ową droga - która w poczuciu odpowiedzialności Chromacjusza za los swoich wiernych po śmierci, nakazywała mu koncentrowanie się w przepowiadaniu na wymiarze egzystencjalnym wiary. Oznaczało to w praktyce nieustanne przypominanie o konieczności dochowania wierności obietnicom złożonym Bogu przed chrztem świętym, których realizacja warunkująca zbawienie, oznaczała podążanie drogą sprawiedliwości prowadzącej do szczęścia wiecznego:

„Dlatego zanim doszedłeś do chrztu, zapytano cię, czy odrzekasz się świata i jego widowisk i jego czynów. I odpowiedziałeś, że się odrzekasz, i tak doszedłeś do łaski chrztu, który cię wiąże na wieki. Słowa twoje u Boga utrzymują swoją moc. Odpowiedź twoja zapisana jest w niebie. [...] Uważaj, co masz czynić! Co się przyrzeka człowiekowi, ma moc ludzką, a jaką jeśli się Bogu ślubuje? Napisano: «Z ust twoich będziesz usprawiedliwiony, albo zostaniesz potępiony» (Mt 12, 37)"’29.

Co więcej, motywowany - jak się wydaje - troską o zbawienie wiernych, stara się Chromacjusz wyjaśnić, co winna oznaczać dla chrześcijanina wierność złożonym Bogu obietnicom. Czyni to, wskazując na liczne zachowania,

\footnotetext{
${ }^{27}$ Por. tenże, Sermo 4, 2; 8, 2; 11, 4; 18, 1; 32, 2; 34, 2; 41, 1.

${ }^{28}$ Por. tenże, Sermo 28, 3.

${ }^{29}$ Tenże, Sermo 14, 4, SCh 154, 244, PSP 49, 51.
} 
zarówno pozytywne, jak i negatywne, które rysując obraz drogi sprawiedliwości, tym samym egzemplifikacyjnie thumaczą aspekt wolitywny aktu wiary. Krótko mówiąc, postępowanie drogą sprawiedliwości, które jest służbą $\mathrm{Bogu}^{30}$, oznacza dla biskupa Akwilei posłuszeństwo woli Bożej wyrażonej w przykazaniach ${ }^{31}$, co przejawia się w wystrzeganiu się niesprawiedliwości ${ }^{32}$, nieczystości ${ }^{33}$, pychy ${ }^{34}$, chciwości ${ }^{35}$, złości ${ }^{36}$, zmysłowości ${ }^{37}$, pożądliwości ${ }^{38}$ oraz bezbożnictwa ${ }^{39}$. Podążającego tą drogą winna jednak, w przekonaniu Chromacjusza, znamionować także pokora ${ }^{40}$, pobożnośćc ${ }^{41}$, służba uczynkom miłosierdzia ${ }^{42}$, bojaźń Boża ${ }^{43}$ i oddanie się Bogu ${ }^{44}$.

Podsumowując wypada krótko stwierdzić, iż dla Chromacjusza istotę aktu wiary stanowi poznanie i działanie - scire et agere, poznanie Chrystusa i dochowywanie wierności Jego nauce. Tym zaś, co spaja oba te elementy jest sakrament chrztu.

2. Owoce wiary. Nie trudno dostrzec, iż owocami wiary są w pierwszym rzędzie konkretne zalety, będące przejawem postępowania drogą sprawiedliwości. Posłuszeństwo woli Bożej wyrażonej w przykazaniach owocuje bowiem - jak to już zostało zaznaczone - sprawiedliwością, czystością myśli i zachowań, pokora, pobożnością, uczynkami miłosierdzia, jak również Bożą bojaźnią i oddaniem się Bogu. Kroczenie drogą wiary przynosi jednak także inne dobra, szczególnie w wymiarze indywidualnym. Jednym z nich, bez wątpienia najważniejszym, jest zbawienie, o czym bardzo często przypomina Chromacjusz swoim wiernym ${ }^{45}$, zachęcając ich tym samym do podążania drogą sprawiedliwości:

„Bądź sprawiedliwy, bądź pobożny, bądź Bogu oddanym, bądź miłosiernym, a będziesz miał u Boga wielkie bogactwa, których ci ani skarb państwa, ani złodziej, ani śmierć nawet nie będzie mogła wyrwać. Mamy przeto wielkie

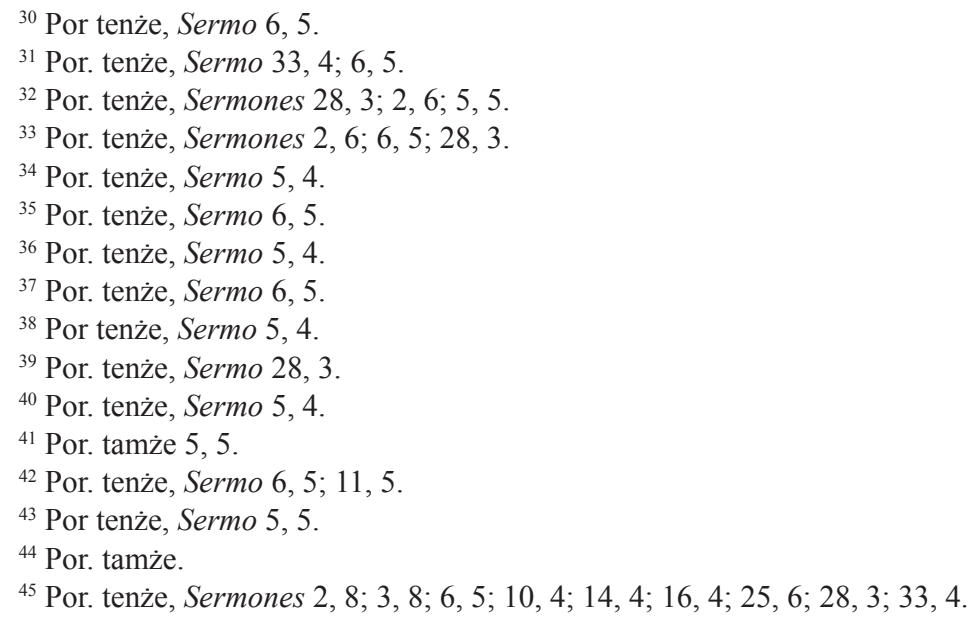


bogactwo dla siebie odłożone, jeżeli przykazania Pańskie zachowujemy, jeżeli wiary dochowujemy, a są to wieczne bogactwa"46.

Czyni to także w kazaniu 5., gdy cytuje fragment mowy Jezusa z Kazania na Górze:

„A na szczyt tej góry wchodzi się nie wysiłkiem ciała, ale wewnętrzną wiarą i myślą. Pozostańmy przeto zawsze na tej górze wzniosłą wiarą, czynami duchowymi, abyśmy zasłużyli na otrzymanie od Pana tych błogosławieństw ewangelicznych, w których mowa: «Błogosławieni ubodzy w duchu, albowiem do nich należy królestwo niebieskie» (Mt 5, 3), i pozostałe"47.

Postępowanie drogą wiary, będące niejako szkołą dla duchowych zmagań człowieka, przynosi także ogrom doświadczeń, dzięki którym łatwiejsze staje się pokonywanie wszelkich trudności i unikanie różnorodnych zagrożeń, jakie pojawiają się na drodze do zbawienia, do którego prowadzi droga sprawiedliwości. W sposób obrazowy mówi o tym Chromacjusz, porównując wiarę do świecącej świecy:

„A świeca dlatego jest postawiona jako obraz wiary, ponieważ jak świeca oświetla drogę chodzącym w nocy, aby nie wpadli w rowy albo w jakieś zasadzki, tak w tej nocy doczesności blask wiary oświetla wszystkie drogi naszego życia, poprzedzając nas ze światłem prawdy, abyśmy nie wpadli w rowy grzechów i w zasadzki diabelskie"48.

Co więcej, ten, kto postępuje drogą sprawiedliwości, staje się niczym duchowy atleta, który, jak mówi Chromacjusz, „potrafi przemóc i zwyciężyć przeciwnika”, wzmocniony „pokarmem sprawiedliwości”49.

Posłuszeństwo woli Bożej wyrażonej w przykazaniach, a więc postępowanie drogą sprawiedliwości, gwarantuje także Bożą pomoc w sytuacji różnych ucisków i prześladowań, będących sprawdzianem naszej wiary. Wymownym tego przykładem jest opisane w Ewangelii (Mt 8, 23-27) wydarzenie uciszenia przez Chrystusa burzy na morzu, która obrazuje różne uciski i prześladowania, jakie Chrystus na krótki czas dopuszcza na ludzi wiary:

„Podczas gdy uczniowie wiosłowali, Chrystus zasnął, co należy tak rozumieć, że na krótki czas dopuścił na swój Kościół - dla wypróbowania wiary - próby ucisku i przejściowe prześladowania ze strony tego świata. «Wtedy przystąpili do Niego i obudzili Go, mówiąc: Panie ratuj nas, giniemy! Wtedy wstał, rozkazał wichrom i jezioru i nastała głęboka cisza» (Mt 8, 25-26). Gdy wiara proszących nic się nie chwieje, ilekroć modlitwy wiernych w ich potrzebach pukają do Pana, szybko wstaje, aby zmiłować się nad nimi. I my, ilekroć

\footnotetext{
${ }^{46}$ Tenże, Sermo 5, 5, SCh 154, 172, PSP 49, 29.

${ }^{47}$ Tamże 5, 3-4, SCh 154, 172, PSP 49, 29.

${ }^{48}$ Tenże, Sermo 6, 1, SCh 154, 174-176, PSP 49, 30.

${ }^{49}$ Tenże, Sermo 12, 7, SCh 154, 230, PSP 49, 47.
} 
jesteśmy przygniatani uciskami i wstrząsami, jakby burzami morskimi, powinniśmy budzić Pana i Zbawiciela naszego natarczywością próśb i wiarą popartą zasługami, aby zmiłował się nad nami, aby raczył podporę i pomoc przynieść ufającym w Jego miłosierdzie [...]"50.

Zdaniem Chromacjusza, wiara przynosi także dobra w wymiarze społecznym. Zaniechanie sporów, walk, jakie znamionowały narody zanim poznały naukę Chrystusa, a także gotowość na męczeństwo w obronie wiary, to owoc czci - jak zaznacza Chromacjusz - oddawanej jednemu Królowi - Chrystusowi:
„Wierzą Persowie, wierzą Hindusi, wierzy cały świat. [...] Wreszcie zobacz- my, jak te narody spierające się między sobą o królestwa, tereny swoje, wy- dzierały sobie kraje i miejscowości, skoro doszły do wiary i wyznają imię Chrystusa, żaden z nich nie walczy z innym [...]. Jego wszyscy czczą [...]. Dla niego zrzucają z siebie usposobienia dzikości [...]. I chociaż w sprawach królestwa ziemskiego rozmaitość ich prowadzi nieraz do niezgody, to jednak w dziedzinie królestwa Bożego i jedności wiary w zgodzie są posłuszne jed- nemu władcy i w wierze wszyscy walczą za Chrystusa. [...] A jeżeli zajdzie potrzeba, raczej są gotowi dusze swe położyć za Króla, niż wiarę utracić" 51 .

Biskup Akwilei jest przekonany, że owocem wiary może być również jednomyślność, wspólnota dóbr i wzajemna miłość, jakimi odznaczali się wierzący w czasach Apostołów. Uzmysławia to swoim wiernym, przytaczając w kazaniu 31. fragment z Dziejów Apostolskich (4, 32): „Jeden duch i jedno serce ożywiały wszystkich wierzących. Żaden nie nazywał swoim tego, co posiadał, ale wszystko mieli wspólne"52. Jednocześnie wyraźnie jednak daje do zrozumienia, iż aby cieszyć się wspomnianymi owocami wiary, należy uprzednio pielęgnować w sobie wolność od skapstwa, chciwości, zazdrości, a także dążyć do zgody i unikać tworzenia podziałów ${ }^{53}$.

3. Niebezpieczeństwo utraty wiary. Biskup Akwilei uzmysławia także swoim wiernym w kazaniach, iż postępujący drogą sprawiedliwości, czyli drogą wiary jest narażony na niebezpieczeństwo jej utraty. Dla Chromacjusza, który podkreśla w swym nauczaniu wymiar egzystencjalny aktu wiary, oznacza to zaniechanie kroczenia drogą sprawiedliwości. Jednym z powodów utraty wiary jest, według Chromacjusza, lekceważenie Bożych przykazań, które prowadzi do zakorzenienia się w człowieku zła:

„[...] nieprzyjaciel wsiewa kąkol, czyli nasienie nieprawości i zdrady. Ale też pokazane zostało wyraźnie, jakim ludziom nieprzyjaciel mógł wsiać takie

\footnotetext{
${ }^{50}$ Tenże, Sermo 37, 2, SCh 164, 204- 206, PSP 49, 106.

${ }^{51}$ Tenże, Sermo 30, 3, SCh 164, 138, PSP 49, 92-93.

${ }^{52}$ Tenże, Sermo 31, 4, SCh 164, 152, PSP 49, 95.

${ }^{53}$ Por. tamże.
} 
nasienie. Powiedział: «Gdy spali ludzie» (Mt 13, 25), u tych nieprzyjaciel wsiał kąkol, których znalazł śpiących, czyli pogrążonych we śnie nieprawości. Zaiste! Czuwających we wierze podejść nie może. Przecież jak długo Adam, w którego sercu Pan wpierw zasiał dobre nasienie, czuwał w posłuszeństwie dla przykazań Pańskich, tak długo nieprzyjaciel ów nie potrafił mu wsiać kąkolu. Lecz skoro znalazł go śpiącego, czyli pogrążonego we śnie niedbalstwa, natychmiast mu zasiał swój kąkol, aby zamiast plonów życia wydał owoc śmiercionośny" ${ }^{4}$.

Na utratę wiary jest narażony również ten, kto osłabiony w wierze, z powodu rozwiązłości, złości, zazdrości, nienawiści, jak również braku zgody, miłości i miłosierdzia, nie karmi się Ewangelią ${ }^{55}$, zawierająca przywracające zdrowie duchowe Boże przykazania:

„Złości i poszczególne wady i grzeszne skłonności są chorobami duszy, a tym konieczne są jakby jarzyny boskiego przykazania, aby mogli powrócić do zdrowia. Tego rodzaju bowiem duchowe jarzyny orzeźwiają dusze słabe, aż wreszcie przywracają najpełniejsze zdrowie. I do tego stosują się słowa Apostoła: «A kto jest słaby, niech je jarzyny» (Rz 4, 12). I to Słowo Pańskie dlatego czytamy: «Oto wam daję wszelką roślinę» (Rdz 1, 29). Wpadł bowiem i pierwszy człowiek w ciężką niemoc grzechową i nie mógłby inaczej zostać uzdrowionym, jak tylko przez żywienie się przykazaniami zbawienia. Przeto, jeżeli nas trzyma jakaś tego rodzaju słabość, chętnie powinniśmy się posilać przykazaniem skromności, przykazaniem czystości, nakazem cierpliwości, przykazaniem miłości i umiłowania, abyśmy mogli powrócić do pełnego zdrowia $[\ldots]^{\prime \prime 56}$.

Chromacjusz jest ponadto przekonany, iż jednym z powodów zaniechania kroczenia drogą sprawiedliwości jest także myślenie, znamionowane brakiem eschatologicznej refleksji, a więc wykluczające perspektywę życia wiecznego, a tym samym i nagrodę wiecznego zbawienia:

„Ale boję się, aby ta jednomyślność i miłość wierzących, która panowała pod Apostołami, nie stała się naszym potępieniem, skoro z powodu zapatrzenia się w chciwość i skąpstwo nie zachowujemy jednomyślności, nie przestrzegamy pokoju, nie szukamy miłości. Oni swoje uważali za wspólne, a my chcemy cudze uczynić naszym. Kłócimy się o granice, posesje, jakbyśmy nigdy nie mieli umierać. Wszystkiego oczekujemy z ziemi, niczego z nieba. Wszystkiego od życia obecnego, niczego od przyszłej chwały i nieśmiertelności. Nie pamiętamy na słowa Pana i Zbawiciela naszego: «Cóż bowiem za korzyść odniesie człowiek, choćby cały świat zyskał, a na swej duszy szkodę poniósł?» (Mt 16, 26) i inne: «Uważajcie i strzeżcie się wszelkiej chciwości,

\footnotetext{
${ }^{54}$ Tenże, Sermo 2, 2, SCh 154, 126, PSP 49, 18-19.

${ }_{55}^{55}$ Por. tenże, Sermo 12, 6.

${ }^{56}$ Tenże, Sermo 12, 8, SCh 154, 232-234, PSP 49, 47-48.
} 
ponieważ nawet gdy ktoś opływa we wszystko, życie jego nie jest zależne od jego mienia» (Łk 12, 15)" ${ }^{\prime 57}$.

Utratę wiary powodować może jednak nie tylko lekceważenie Bożych przykazań, brak umacniającej lektury Słowa Bożego, czy negacja prawdy o przeznaczeniu człowieka do życia wiecznego. Niezmiernie ważne w kroczeniu drogą wiary jest świadectwo życia dawane przez pasterzy, a zwłaszcza biskupów. Ich niewierność, czy niedbalstwo mogą bowiem spowodować zagubienie powierzonych ich pieczy wiernych, a nawet zaprzestanie podążania drogą zbawienia ${ }^{58}$.

Podsumowując powyższe rozważania wypada stwierdzić, iż Chromacjuszową wizję wiary dobrze oddają słowa z Listu św. Jakuba, że wiara bez uczynków jest martwa (por. Jk 2, 17). Analiza jego kaznodziejskiego nauczania uwidacznia bowiem, że dokonując wykładni tego zagadnienia, skupia się on w głównej mierze na wymiarze egzystencjalnym wiary, ukazując ją tym samym jako kroczenie drogą sprawiedliwości. Podążanie tą drogą wiąże się z koniecznością dochowywania wierności przyrzeczeniom złożonym przed chrztem świętym, czego wyrazem jest posłuszeństwo woli Bożej wyrażonej w przykazaniach. Koncentrowanie się na wymiarze egzystencjalnym wiary, będące oznaką rezygnacji z polemiki z arianizmem, przejawia się także w ukazaniu owoców podążania drogą sprawiedliwości, jak również w zwróceniu uwagi na możliwość utraty wiary. Choć dla Chromacjusza wiara oznacza przede wszystkim działanie, to nie lekceważy on tym samym jej aspektu doktrynalnego. Podkreśla bowiem, iż aby kroczyć drogą wiary konieczne jest poznanie Chrystusa - drogi zbawienia, które dokonuje się poprzez głoszenie Ewangelii. Poznanie Chrystusa, a także Jego nauki jest jednak niemożliwe bez akceptacji wydarzenia Wcielenia, które stanowi zasadniczy element aspektu doktrynalnego. Podkreślenie tego faktu bez oznak polemiki z arianizmem, nie oznacza lekceważenia innych elementów chrystologicznych chrześcijańskiej doktryny. Wyczuwalny jednak w przepowiadaniu Chromacjusza ich niedosyt, a przede wszystkim mogąca budzić zastrzeżenia ich wykładnia, nie dawały z pewnością słuchaczom jego kazań wystarczającego przygotowania do podjęcia polemiki z arianizmem na gruncie doktrynalnym. Nieprzywiązywanie większej wagi do doktrynalnego aspektu wiary, mogło wyrastać, jak się wydaje, z przekonania Chromacjusza, iż wszyscy dostapimy usprawiedliwienia na podstawie uczynków (por. Jk 2, 24).

\footnotetext{
${ }^{57}$ Tenże, Sermo 31, 4, SCh 164, 152, PSP 49, 95-96.

${ }^{58}$ Por. tenże, Sermo 32, 4; 6, 2.
} 


\title{
ISSUES OF FAITH IN THE PREDICATORY TEACHING OF ST. CHROMATIUS OF AQUILEIA
}

\begin{abstract}
(Summary)
St. Chromatius, bishop of Aquileia, who lived at the turn of the IV and V century, as a zealous pastor, led by concern for the salvation of his faithful, undertook in his predicatory teaching an explanation of the queations of faith. Without indications of any polemics - as one might expect - with the Arianism which was spread through the Gothic invaders, he did it, not ignoring however the important doctrinal aspect which constitutes the basis of the act of faith. He teaches, that to believe means to walk incessantly the Christ's way of righteousness, know thanks to the proclaimed Gospel. Receiving the holy baptism is the beginning of that way. In a simple, but interesting at the same time, preaching being not infrequently the fruit of an allegorical, often amazing interpretation of the Bible events and signs know to his listeners, the bishop of Aquileia furthermore encourages to fidelity to the chosen way of righteousness, making his listeners aware that walking this way means not only walking a way that is free from wrongdoing, which brings concrete fruits, of which the most valuable is the eternal salvation. Being aware of many menaces in spiritual life, he also warns in his sermons against the danger of losing the faith.
\end{abstract}

Key words: Chromatius of Aquileia, faith, sermons.

Słowa kluczowe: Chromacjusz z Akwilei, wiara, kazania. 